\title{
Growth, Yield and Chemical Composition of Peas (Pisum sativum) as Affected by Potassium Levels and Different Methods of Yeast Application
}

\author{
Gehan A. Elsharkawy ${ }^{1}$
}

\begin{abstract}
Two field experiments were carried out at the Experimental farm, Faculty of Agriculture, Alexandria University during 2008 and 2009 winter seasons. The aim of the current study was to investigate the effects of potassium levels $\left(0,24,48,72 \mathrm{~kg} \mathrm{k}_{2} \mathrm{o} /\right.$ fed.), methods of yeast application (without, foliar and soil) on vegetative growth characters, green yield and its components and chemical constituents of green seeds of the new introduced pea cultivar "Balmoral". The results indicated that foliage fresh weight, foliage dry matter, no. of pods / plant, weight of pods / plant total yield (ton/ fed.), $\mathrm{N}$, protein and $\mathrm{K}$ content in green seeds were significantly and positively affected by increasing potassium levels and the maximum promotion was detected at $48 \mathrm{~kg} \mathrm{k}_{2} \mathrm{O}$ / fed. and beyond this dose a significant reduction was detected in both growing seasons. It is clear that adding $48 \mathrm{~kg} \mathrm{k}_{2} \mathrm{O} /$ fed. showed maximum significant increase of $32 \%$ and $16 \%$ for total yield and $18 \%$ and $19 \%$ for green seed protein more than the control in the first and second seasons, respectively. Application of yeast extract either foliar or soil addition showed progressive increase for plant height, vegetative weight, number and weight of pods / plant, $\mathrm{N} \%$, protein content and total yield (ton/fed.) compared to control (without adding yeast). The highest green yield obtained by soil application of yeast extract (1.61 and $2.08 \mathrm{ton} /$ fed.) in both studied seasons. Addition of $48 \mathrm{~kg}$ $\mathbf{k}_{2} \mathrm{o} /$ fed combined with soil application of yeast extract gave the highest total yield / fed. 2.01 and 2.25 ton / fed. with the highest protein content of green seeds, in both growing seasons.
\end{abstract}

\section{INTRODUCTION}

Pea (pisum sativum) which is commonly known in Egypt as "Besela" is a tender annual winter crop .It is one of the most important vegetable crops in Egypt which is consumed as a cooked green seeds. Peas is full of nutrition because its grain is cheap source and rich in protein content $(27.8 \%)$, as well as, complex carbohydrates $(42.65 \%)$, vitamins, minerals dietary fibers and antioxidant compounds (Urbano et al., 2003). Economically pea is a predominate export and cash crop in world trade and represents about $40 \%$ of the total trading in pulses for both fresh use and processing (Oram \& Agcaolili, 1994). Increasing yield of pea in Egypt is highly recommended to meet the demand of human needs, so improve agricultural practices and cultivate high yielding cultivars is very important.
Bio stimulus like yeast (Saccharomyces cerevisiae) is a microorganism with the objective of increasing its number and of accelerating certain microbial process to increase the availability of nutrients element in form which can be easily taken by plants without any pollution to the environment (Kraig and Hober 1980). It is used as a kind of bio fertilizers in soil fertilization or in foliar application on the shoot of vegetable crops (Barnett et al .1990). A great attention has been paid on the possibility of using natural and safety substances which are rich sources of phytohormons in order to improve plant growth, flowering and fruit setting. In this connection, yeast have been reported to be rich source of phytohormones, amino acids, vitamins, enzymes and minerals (Barnett et al. 1990, and Glick 1995). Improving growth and productivity of Legume crops by application of active yeast extract were recorded by El Desuki and El Greadly 2006 .and Mahmoud et al .(2013) and Fathy and Farid (1996), (Amer 2004), El Tohamy and El Greatly (2007), Fawzy et al. (2010) and Nassar et al (2011) on legumes.

Potassium application is essential to obtain high yield, since it plays an important role in many processes in plant cells. It is often referred as the quality element for crop production due to its positive interaction with other nutrients (Usher wood, 1985) .It promotes synthesis of photosynthesis and transport to fruit and grains and enhances their conversion into starch, protein, vitamins (Mengel and Kirkby, 1997). Application of potassium also enhanced vegetation growth and increased pod yield in pea as reported by many investigators (Kanaujia et al .1997and 1998), Nadeem Akhtar et al 2003, Shafeek et al 2005. Thus plant nutrition is an important factor for obtaining higher yields of green pods, which need to be studied under local conditions as soil fertility varies greatly and response varies from cultivar to cultivar. Therefore the preset work was conducted to study the effect of various levels of potassium and compare the effect of soil and foliar application with yeast extract on growth, productivity and chemical composition of new introduced pea cultivar Balmoral grown for the first time under Alexandria environment.

\footnotetext{
${ }^{1}$ Department of vegetable crops, Faculty of agriculture,

Alexandria University

Received November 10, 2013, Accepted December 09, 2013
} 


\section{MATERIALS AND METHODS}

Two field experiments were carried out during the two successive winter season of 2008 and 2009, respectively at the Experimental station Farm, faculty of Agriculture, Alexandria University to study the effect of different levels of potassium and methods of yeast application on growth, yield and quality of a new promising high yielding pea cultivar; Balmoral which is late in maturation, its origin is England and it is grown for the first time under Alexandria condition. Soil physical and chemical properties of the experimental sites during winter season of 2008 and 2009 were presented in Table (1).

All treatments received the recommended dose of nitrogen (40kg N/fed.) as ammonium nitrate $(33.5 \% \mathrm{~N})$ which were added twice, 15 days after planting and 15 days after that. Phosphorus was applied as one dose at the time of bed preparation at $100 \mathrm{~kg} / \mathrm{fed}$. as superphosphate. The potassium fertilizer levels were 0 , 24,48 and $72 \mathrm{~kg}$ / fed in the form of potassium sulphate $\left(48 \% \mathrm{k}_{2} 0\right)$ and were applied, to each plot, in two halves the $1^{\mathrm{St}}$ one was applied at the time of initiation of flowering, while the $2^{\text {nd }}$ was applied at the time of pods formation. All field practices were carried out as recommended for the studied crop in the vicinity.

Active dry yeast was dissolved in distilled water followed by adding sugar at ratio of $1: 1$ and kept overnight for activation and reproduction of yeast cells to produce extract before application to the plant at the rate of $4 \mathrm{~g} / \mathrm{L}$. The plants were treated with yeast extract in two different methods, the first was foliar application and the second was drench application (adding almost the same amount of yeast extract beside each plant root), in addition to control without yeast extract application. The plants were treated by these treatments two times during the crop life. The first application was after 30 days from planting and the second was two weeks later. The plants were sprayed or adding drench (soil application) with the same amount of extract /plant. The yeast solution contained protein $47.2 \%$, arginine $2.6 \%$, glycine $2.6 \%$, histidine $1.4 \%$, isolysin $2.9 \%$, louicine $3.5 \%$, lysine $3.8 \%$, methionine systine $0.6 \%$, phynyl alanine $3 \%$, tyrosine $2.1 \%$, threonine $2.6 \%$ ,tryptophan $0.5 \%$ and vitamin B $2.9 \%$ in addition to carbohydrates, fatty acids, hormones macro and micro elements in suitable balance (N.R.P.1997).

Seeds of peas were sown on 10 November 2008 in the first season and replicated on 5 November 2009 in the second one. Seeds were sown on one side of the ridge, $20 \mathrm{~cm}$ apart. A split plot design with four replications was used. The four different levels of potassium fertilizer used were $0,24,48,72 \mathrm{~kg} \mathrm{k} 20 /$ fed. which were laid out in main plots while, the three methods of yeast application (without, foliar and soil) ,were distributed randomly in the sub-plots.

Table 1. Some physical and chemical characteristic of the experimental soils

\begin{tabular}{|c|c|c|}
\hline Properties & Season 2008 & Season 2009 \\
\hline \multicolumn{3}{|l|}{ Physical properties } \\
\hline Clay \% & 46.1 & 39.6 \\
\hline Silt \% & 33.0 & 36.2 \\
\hline Sand $\%$ & 20.9 & 24.2 \\
\hline Soil texture \% & Clay loam & Clay loam \\
\hline \multicolumn{3}{|l|}{ Chemical properties: } \\
\hline$* \mathrm{PH}$ & 8.2 & 8.4 \\
\hline$* * \mathrm{EC}\left(\mathrm{dSm}^{-1}\right)$ & 3.38 & 3.34 \\
\hline \multicolumn{3}{|l|}{ Soluble cations (meq/l): } \\
\hline $\mathrm{Ca}++$ & 4.8 & 3.9 \\
\hline $\mathrm{Mg}+$ & 1.9 & 3.5 \\
\hline $\mathrm{K}+$ & 18 & 20 \\
\hline $\mathrm{Na}$ & 7.4 & 6.9 \\
\hline \multicolumn{3}{|l|}{ Soluble anions: } \\
\hline $\mathrm{CO}_{3}^{--}$ & 3.5 & 3.2 \\
\hline $\mathrm{HCO}_{3}^{-}$ & 1.9 & 1.8 \\
\hline $\mathrm{Cl}^{-}$ & 5.7 & 5.3 \\
\hline $\mathrm{SO}_{4}^{--}$ & 3.3 & 2.4 \\
\hline Total N\% & 0.16 & 0.18 \\
\hline Available phosphorus $\quad$ (ppm) & 31.5 & 31.8 \\
\hline
\end{tabular}

*measured in 1:25 soil water suspension.

**measured in the water extract of saturation soil paste. 
The plot area was $12.25 \mathrm{~m}^{2}$ and included 5 rows (each was $3.5 \mathrm{~m}$ length and $70 \mathrm{~cm}$ width). Harvesting were done two times at first of march and two weeks later in both growing seasons.

\section{Sampling and Analysis:}

a- Vegetative growth and plant yield: A random sample of 5 plants from each plot was taken at the first harvest time and the following characters were measured: plant height $(\mathrm{cm})$, fresh weight of plant (gm), foliage dry matter $\%$.

b- Plant yield: yield of five randomly selected plants from each sub plot were obtained to determine, No of pods/ plant, weight of pods /plant (gm) and \% of net green seeds / plant.

c- Total yield: At harvest stage the mature pods of pea from each experimental plot were collected along the harvesting season, total yield was recorded as $\mathrm{kg}$ $/$ plot then converted to ton $/$ fed $(1 \mathrm{fed} .=0.4$ hectare).

d- Pods quality: - random sample of 20 pods from each plot was taken and the physical properties (pod length $(\mathrm{cm})$, pod diameter $(\mathrm{cm})$, No of seeds / pod) and dry matter of green seeds \%were recorded.

e- Chemical constituents of green seeds: N\%, P\%, K ppm content were determined according to the methods mentioned by Black (1983), and Brown and Lilleland (1995). The protein percentages in green seeds were accounted by multiplying nitrogen content by 6.25 . Starch (\%) and sugar $\%$ content was measure according to Dubois et al (1956) .

\section{Statistical Analysis:}

The collected data were subjected to statistical analysis of variance using Co- Stat Program and the means were compared by using revised LSD test at 5\% level of significance according to Snedecor and Cochran (1980).

\section{RESULTS}

\section{A. Vegetative growth characters.}

The effect of Potassium levels application on vegetative growth characters showed that plant height was not affected by potassium levels while potassium had significant effect on foliage weight and foliage dry matter \% which were significantly increased with linear increase in applied $\mathrm{k}_{2} \mathrm{O}$ fertilizer (table 2). Maximum foliage weight and foliage dry matter \% were recorded by using $48 \mathrm{~kg} \mathrm{k}_{2} \mathrm{O} / \mathrm{fed}$. beyond this, significant reduction was measured in both season.
Concerning the effect of different methods of yeast application the data indicated that both soil and foliar yeast application significantly increased plant height, foliage weight and foliage dry matter. The lowest values for all the previous character were obtained in control treatment (without yeast application). However, there were no significant difference between soil and foliar yeast application as shown in both growing season, except for foliage dry matter in the second season which no significant differences were detected between the studied treatment.

Table (2) showed also the effect of interaction between treatments. The results indicated that the foliage plant weight and foliage dry matter were significantly affected by the interaction between potassium levels and methods of yeast application. However, plant height was not significantly affected. These results are true in both growing seasons. The highest level for foliage plant weight and foliage dry matter were recorded with adding $48 \mathrm{~kg} \mathrm{k}_{2} \mathrm{O}$ fed. combined with using soil application of yeast extract.

\section{B. Yield and its components}

Data presented in Table(3) showed that the statistical analysis of the obtained data revealed significant differences between different potassium levels in relation to productivity of pea plant, No of pods / plant and total yield/ faddan. However, the results showed that, potassium. treatment did not significantly affect pod length, pod diameter, No of seeds / pod and \%of net seed weight/ plant. whereas, all Potassium dosses produced significantly greater total yield/ fed. as compared with control. However, potassium at $48 \mathrm{~kg} \mathrm{k}_{2} 0 /$ fed. statistically out yielded the other potassium treatments by producing 1.7 ton /fed .and 1.86 ton/fed. in first and second seasons, respectively and beyond this dose a significant reduction was observed. Regarding the effects of potassium on pod weight and number / plant; the results followed the same pattern of significance and presented the same picture as total yield /fed.

For the effect of different methods of yeast application, the data illustrated in Table (3) showed that almost both methods of yeast application caused significant increase in yield and its components compared with control plants with exception of pod diameter and pod length which there difference did not reach the significance level. The data also revealed that the highest significant means in yield parameters appeared in plant treated with soil application of yeast extract in relation to No of pods /plant, weight of pods /plant, green seed/plant and total yield fed. 


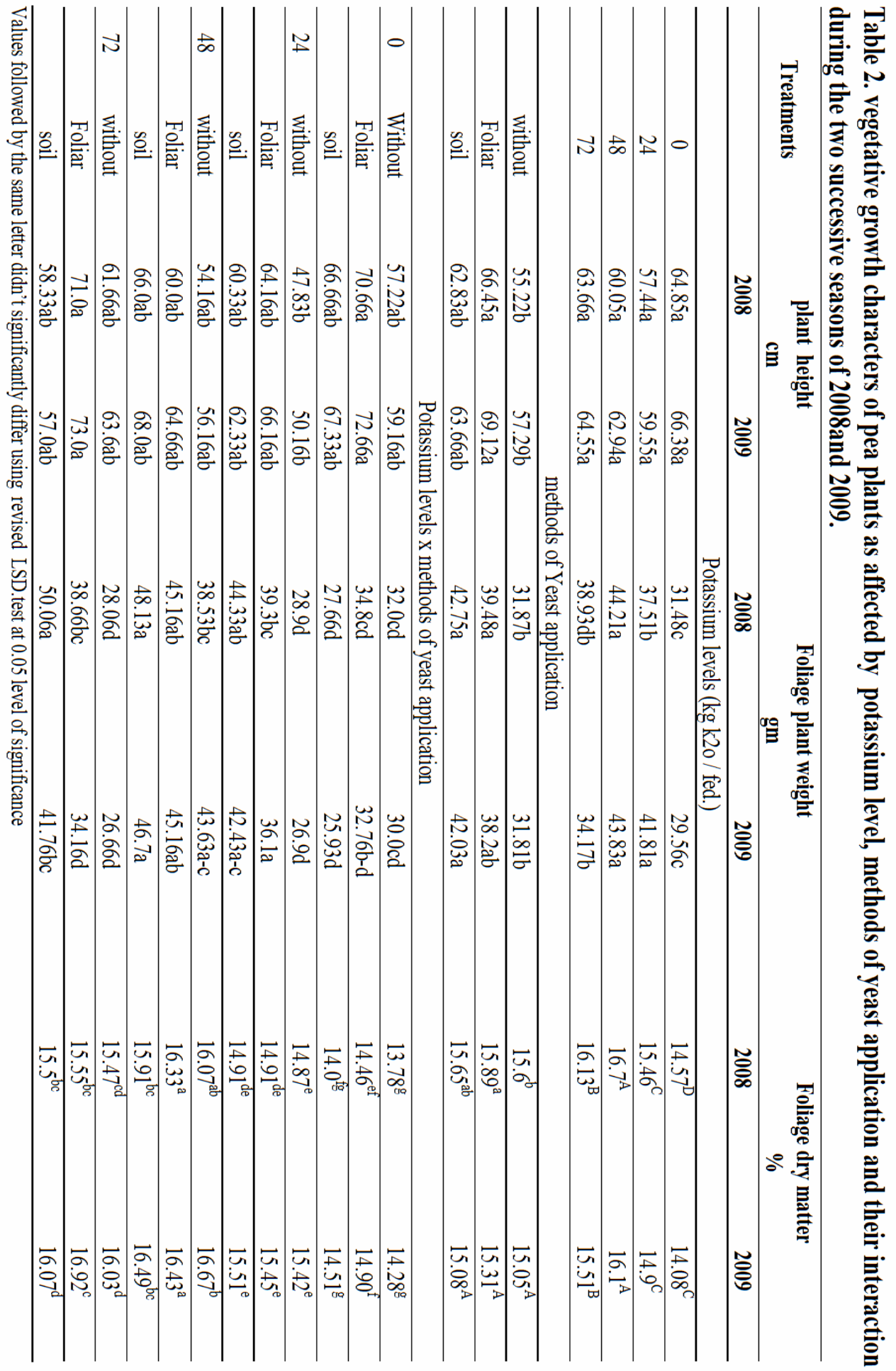




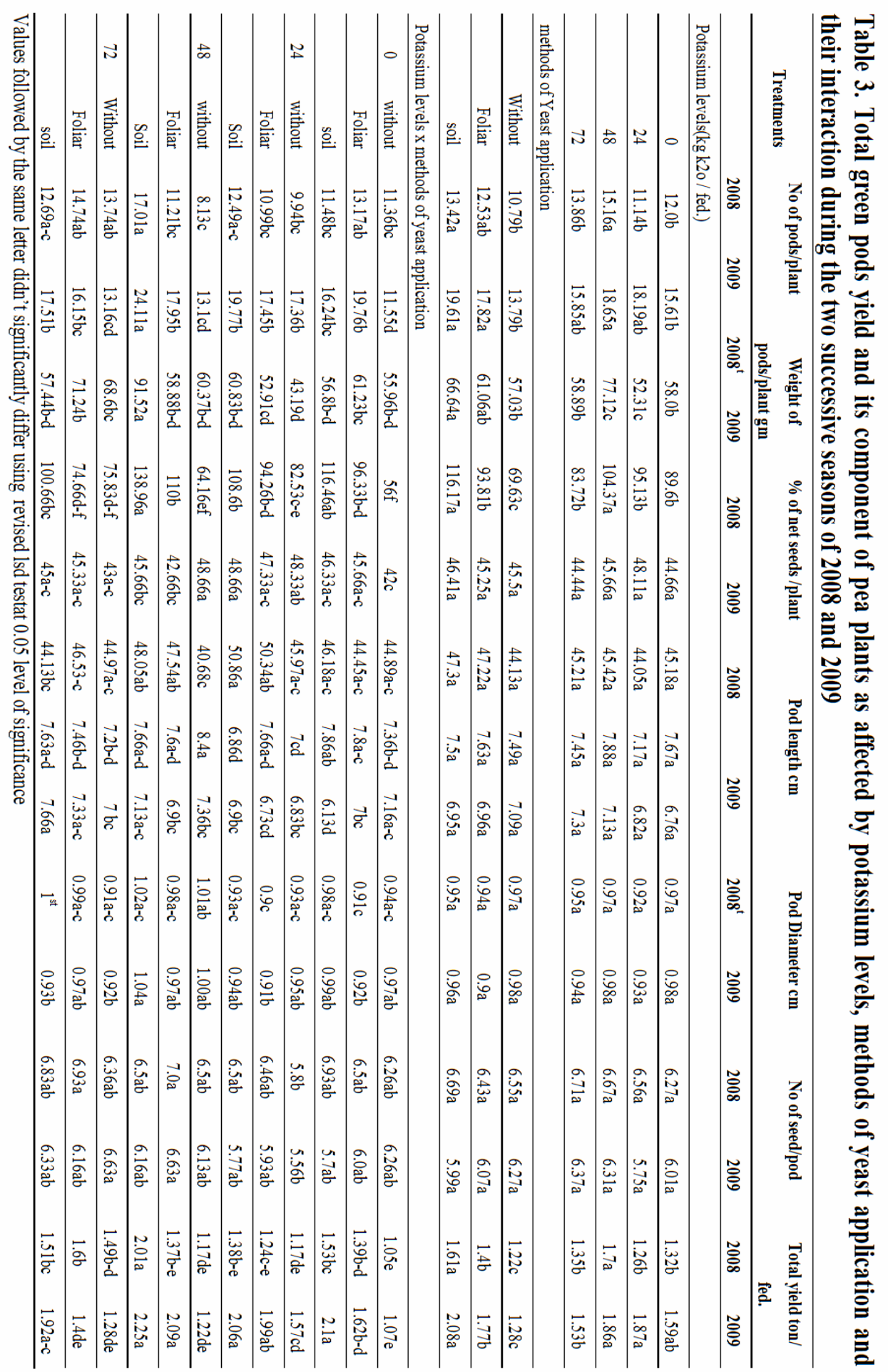




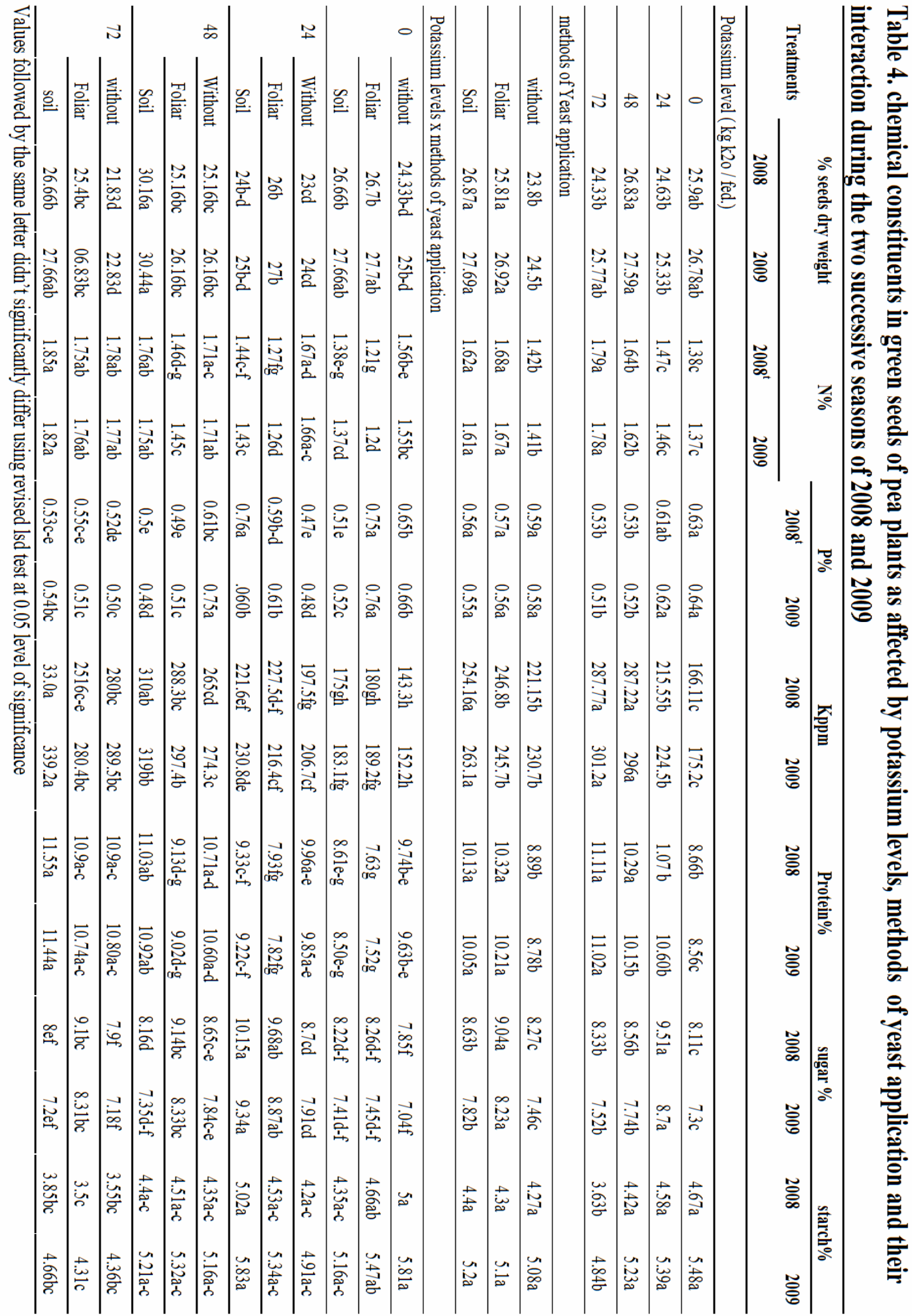


The highest value of total yield /Fed. were amounted 1.61 and $2.08 \mathrm{ton} / \mathrm{fad}$ for the first and second seasons respectively. whereas, the lowest value were recorded with the corresponding untreated plants with yeast extract.

Data in table (3) show the effect of interaction between potassium level and method of yeast application on yield and its component of pea. The data indicated the presence of significant effect on all yield characters of pea plants. The highest value of total yield as ton /fed. was obtained with pea plants fertilized with $48 \mathrm{~kg} \mathrm{k}_{2} \mathrm{O} /$ fed combined with soil application of yeast in both seasons. On the other hand, the lowest values were recorded with control (without yeast application) plants in both studied seasons. The same trend of results were found for No of pods /plant, weight of pods /plant, pod diameter where, $24 \mathrm{~kg}$ $\mathrm{k}_{2} \mathrm{O} /$ fed combined with soil application of yeast gave the highest values for green seeds / plants.

\section{Chemical constitution in green seeds:-}

Data in table (4) showed the effect of potassium level on the chemical constitutions of pea green seeds. Results indicated that $\mathrm{N} \%, \mathrm{~K}$ ppm and \% protein contents were gradually and significantly increased by increasing the level of potassium used up to $72 \mathrm{~kg}$ $\mathrm{k}_{2} \mathrm{O}$ /fed . whereas, $\mathrm{P}$, dry matter contents and starch were slightly decreased by increasing potassium levels. For \%sugar content the highest was obtained by using $24 \mathrm{~kg} \mathrm{k}_{2} \mathrm{O} / \mathrm{fed}$. These results are true in both growing season.

Concerning, application of yeast by different methods resulted showed significant increase in Nitrogen, K, protein sugar and dry matter content as compared with control treatment. The maximum values were obtained in plants treated with soil application where the differences between the two treatments were insignificant. On the other hand, concerning $\mathrm{P}$ and starch the difference between the two methods of yeast were not high enough to be significant. These findings are true in both studied seasons.

For the effect of interaction between the two studied factors, the data showed significant potassium effect on all studied characters except \% starch content. The highest value of $\mathrm{N}, \mathrm{k}$ and protein were obtained with pea plants supplied with the highest Potassium level of $72 \mathrm{~kg} \mathrm{k} \mathrm{O}_{2} /$ fed. combined with soil application with yeast, whereas, the highest values record of of starch appeared in plants treated with yeast as soil application and $48 \mathrm{~kg} \mathrm{k}_{2} \mathrm{O} /$ fed. Meanwhile, seed dry matter, $\mathrm{P}$ and sugar contents, showed no clear trend in that respect.

\section{DISCUSSIONS}

The increments of vegetative growth characters of pea plants and improving green pods yield and pod quality by increasing the level of potassium used in this study might be attributed to that soil analysis showed a low available K concentration Table (1). Therefore, soil applicatiom with $\mathrm{K}$ probably increased soil exchange $\mathrm{K}$ and consequently, enhanced the translocation of $\mathrm{K}$ to the plants. Potassium also functions as co-factor or activator of several enzymes involved in protein and carbohydrate metabolism (Evans and Wildes 1971) beside its role in ionic and osmotic regulation. The results are in harmony with those reported by Kanaujia et al.(1999). Jamadagni and Birari (1994) who reported that the extent of variation in yield of cow pea due to $\mathrm{K}$ was greater than due to $\mathrm{P}$.Many researchers reported the importance of potassium in different crops like Ezzat and khalil (2005). Siquira et al (1985)and Romer and lehne (2004) who found that insufficient K supply to legumes may reduce their $\mathrm{N}_{2}$ fixation capacity; consequently the total yield may also reduce.

In addition the improving of vegetative growth characters of pea plants, pods yield and pods quality by using yeast extract application may by due to that, yeast extract are natural component safe, and not pollutant contain many of the nutrient elements and cytokines (Castelfranco and Beale 1983). Yeast contain also a considerable amounts of amino acids, minerals, carbohydrates enzymes and vitamins B1, 2, 3, 12 (Spencer et al 1983) and (Khedr and Farid 2000)

The soil application of yeast gave a higher values for vegetative and pod yield characters of peas in this study may be due that, yeast could also act as a good source for bio fertilizer to enrich rhizosphere with important yeast residuals,

The importance of yeast extract application on vegetative growth characters and pod yield of pea plant as a foliar supplement were reported by many researchers like mahmoud et al (2013), Eldesouki and El Gereadly (2006). In addition, several studies indicated that plant root growth may be directly or indirectly enhanced by yeast in the rhizosphere (Agamy et al. 2013) and (Cloete et al 2009).

It can be concluded that applying potassium to peas plants at the rate of $48 \mathrm{~kg} \mathrm{~K} \mathrm{~K}_{2} \mathrm{O} /$ fed. combined with yeast extract as a soil application improve the vegetative growth of pea plants and gave the highest yield potential with quality as well as, nutritive value of pea green seeds. 


\section{REFERENCES}

Agamy, R., M. Hesham,and S. Alamri, 2013. Effect of soil amendment with yeasts on biofertilizers on the growth and productivity of sugar beet. African Jour. Agric. Res. $8(1): 46-56$.

Amer, S.S.A., 2004. Growth, green pods yield and seeds yield of common bean as affected by active dry yeast, salicylic acid and their interaction. . J. Agric. sci. Mansoura. Univ., 29 (3):1407-1727.

Barnett, J.A., R.W. Payne and D. Yarrow. 1990. Yeasts, characteristics and Identification. Cambridge University Press, London, 999 pp.

Black, C.A., 1983. Methods of plant Analysis. Parts I and II. Soc. Agron. Ins. Publ. Madison, Wisc, USA.

Brown, J.D.and O. Lilleland, 1995.Rapid determination of potassium and sodium in plant material and soil extracts by flam photometry. Proc. Amer. Soc. Hort. Sci., 46:341364.

Castelfranco, P.A. And S.I. Beale, 1983. Chlorophyll biosynthesis: recent advances and area of current interest. Ann. Rev. Plant physiology. 34:241-278.

Cloet, K., A. Valentine, M. Blomerus and A. Botha (2009). Evidence of symbiosis between the soil yeast Cryptococcus laurentii and a sclerophyllous medicinal shrub, Agathosma betulina (Berg). Pillans. microb. Ecol 57:62

Dubois, M.A., W.F. Geddes and F. Smith, 1960. The carbohydrate of the Gramineae .X-A Quantitative study of carbohydrates of wheat germ. Cereal Chem., 37; 557.

El-Desuki, M. and N.H.M. El-Greadly, 2006. Response of pea plants to foliar of yeast extract. J. Agric. sci. Mansoura. Univ., 31(10):6667-6674.

El-Tohamy, W.T.A. and N.H.M. El-Greagly. 2007. Physiological responses, growth, yield and quality of snap beans in responses to foliar application of yeast, vitamin E and zinc under sandy soil conditions. Aust. J. Basic. Appl. sci. 1 (3): 294-299.

Evans, H.J. and R.A. wilds. 1971. Potassium and its role in enzyme activation .potassium Biochen physiol, PP: 13-39.

Ezzat, Z.M., K. M. Khalil, 2005. Effect of natural potassium fertilizer on yield, yield components and seed composition of Lentil in old and new reclaimed lands. Egypt J. Applied Sci. ,20:80-92.

Fathy,E.S.L. and S.Farid, 1996. The possibility of using vitamin B and yeast to delay senescence and improve growth and yield of common bean (phaseolus vulgaris) .J.Agric.Sci.MansouraUniv.,21(4):1415-1423.

Fawzy. Z. F., A.M. EL-Bassiony, A. G. Behairy and Y. I. Helemy. 2010. Effect of foliar spraying by some bio and organic compounds on growth, yield and chemical composition of snap bean plants. J. Appl. sci. Res. 6 (12): 2269-2274.

Glick, B. R., 1995 the enhancet of plant growth by free living bacteria. Canada. J. Microbiology, Qi: 109.117.
Jamadagni, B. M. and S. P. Birari. 1994. Yield response of cowpea to varying levels of potassium and phosphorus on latertic soil of Kankan region, J. Potassium. Res. 10: 192195.

Kanaujia, S.P., K.B. Rastogi and S.K.Sharma. 1997. Effect of phosphorus potassium and Rhizobium inoculation on growth, yield and quality of pea cv. Lin colin. Vegetable Sci.,24: 91-94.

Kanaujia, S.P., R. Narayan and S.Narayan 1999 .Effect of phosphorus and potassium on growth, yield and Quality of French beau CV. Contender . Vegetable. Sci . 26:91-92.

Kanaujia, S.P., S. K.Sharma. And K.B. Rastogi. 1998. Effect of phosphorus potassium and Rhizobium inoculation on growth and yield of pea. Ann. Agric. Res. 19: 219-221.

Khedr, Z.M.A. and S. Farid, 2000. Response of naturally infected tomato to yeast extract and phosphoric acid application. Annals ofAgric. Sci. Moshtohor,38(2):927393.

Kraig, E.and J.E. Haber, 1980.Messenger ribonucleic acid and protein metabolism during sporulation of Sccharomyces cerevisiae .J. Bacterial. 144:1084-1112.

Mahmoud, R.A; M, El-Desuki, M. Abdel.mouty and A.H. Ali.2013. Effect of compost levels and yeast extract application on the pea plants And quality. Jour. Appl. Science. 9 (1):149-155.

Mengel, k. and F.A. Kirkby. 1997-principles of plant nutrition, 4TH Ed. International potash institute, Bern, Switzer land, P.685.

N.R.P., 1997. Nutrient requirements of domestic animals (rabbit), no. $17^{\text {th }}$ Rev .Ed., p.16-26. National Academy of Science, Washington, D.C.

Nadeem, A. M. Amjad and M.A. Anjum; 2003. Growth and yield response of pea crop to phosphorus and potassium application pak. J. Agric. Sci. 40: 3-4.

Nassar, R. M. A, A. M. Yasser and D. M. A. Nassar. 2011. Effect of foliar spray with active yeast extract on morphological, Anatomical and yield characteristics of kidney bean. Aust, J. Basic. App. sci. 5 (5): 1071-1079.

Oram, P.A. and M.Agcaolili. 1994. Current status and future trends in supply and demand of cool season food legumes. pp:-49(Ed): R.J. summer field, world crops: cool season food legumes .Kluwer Acad .Pub Dordreach, Netherland

Romer, W. and P. Lehne, 2004. Neglected $\mathrm{p}$ and $\mathrm{k}$ fertilization in organic farming reduce $\mathrm{N}_{2}$ fixation and grain yield in a red clover oat rotation. J. Plant Nutr. Soil Sci., 167: 106113.

Shafeek, M. R., O. A. H. EL- Zeiny and M. A. Ahmed. 2005. Effect of phosphate and potassium fertilizer on growth, yield seed composition of pea plant in new reclaimed soil. Ass. J. plant. Sci. 4 (6) : 608-612.

Siqueira, J.O., G.A.A. Guedes and M.A.V. Ribiero, 1985. Availability of the potassium of maize Pesqyisa Agropecuaria Brasiliera, 20: 299-307.

Spencer, T.F.T., S.M. Dorothy and A.R.W. Smith, 1983. Yeast genetic fundamental and applied aspects. Pp. 16-18 ISBNO-387-90973-9. Springer- Verlag New York ,USA. 
Urbano G, P Aranda and E Gomez -Villalva, 2003. Nutritional evaluation of pea (pisum sativum) protein diets after mild hydrothermal treatment and with and without added phytase. Journal of Agricultural and food chemistry, 51:2415-2420.
Usherwood, N.R. 1985. The role of potassium in crop Quality .In. Munsor, R.S.(ED). Potassium in Agriculture. ASA. CSSA. SSSA, Madison, WI, USA, PP.489-513.

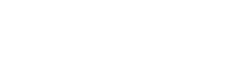

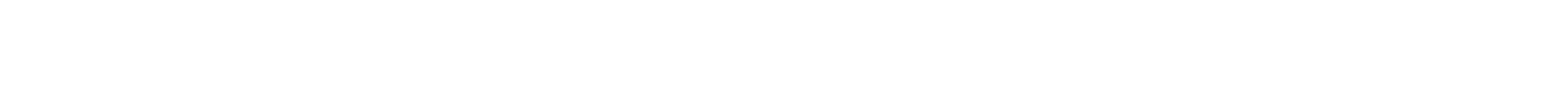

\section{لالبسلة}

جيهل عبد العزيز المشرقاوي

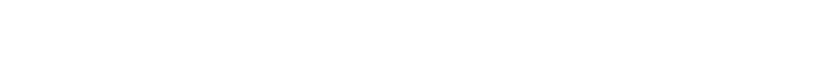

إلصولة.

لظاهرت تنائج للستخدم مستخلص الـمهة وجود زياة معنوية

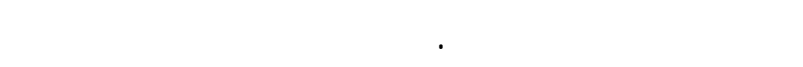

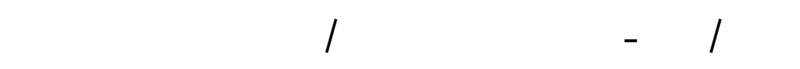

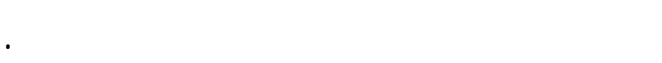
لظٔلهرت تائج هذه الدرلسة ألضا لن الإضلة الأرضية لمستخلص

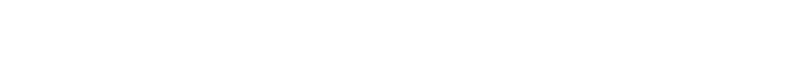

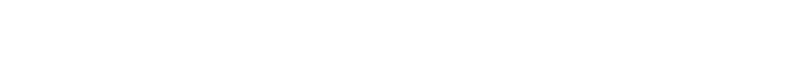
اللهستخلص من مركبلت منشطة للنمو كبض الفيتلمينت ومظملت الموو الأهلهن المينية.

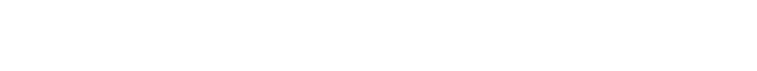

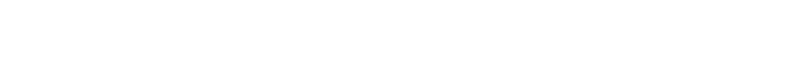

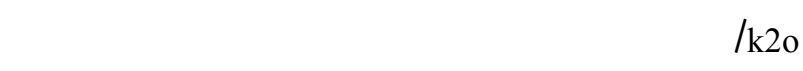

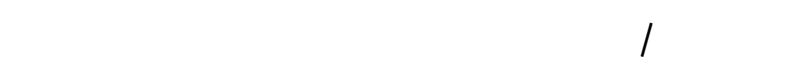
الصفت الصضرية وإصصولية والنزكيبقي بذور البسلة الصضرك.

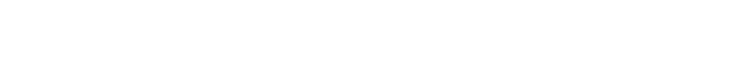

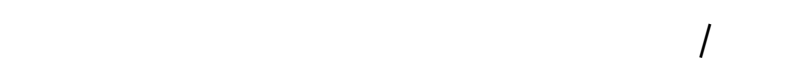

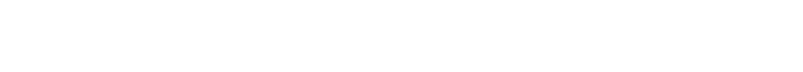

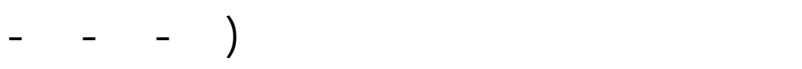

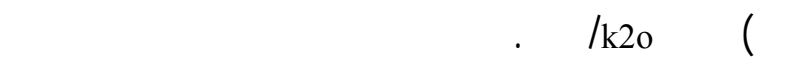

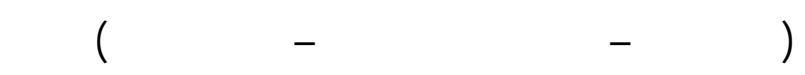

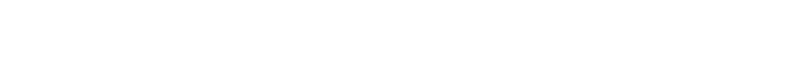
الكيماوي لبذور البسلة الصضراء وكلت أهم التنائج المنهطل عليها

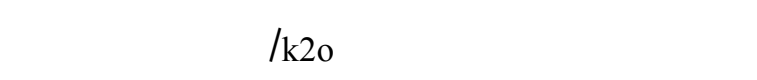

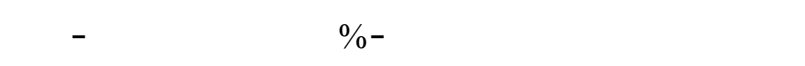

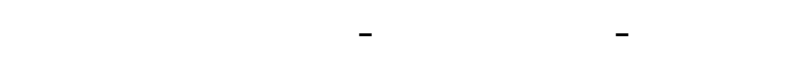

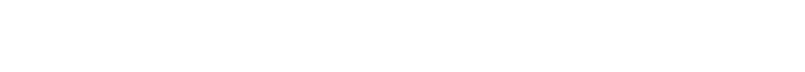

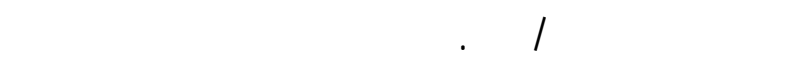

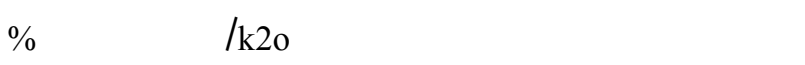

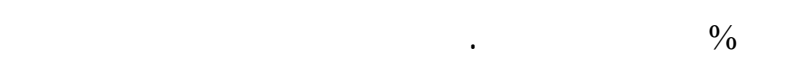

